\title{
Green Peach Aphid, Myzus persicae (Sulzer) (Insecta: Hemiptera: Aphididae) ${ }^{1}$
}

John L. Capinera²

\section{Distribution}

The green peach aphid, Myzus persicae (Sulzer), is found throughout the world, including all areas of North America, where it is viewed as a pest principally due to its ability to transmit plant viruses. In addition to attacking plants in the field, green peach aphid readily infests vegetables and ornamental plants grown in greenhouses. This allows high levels of survival in areas with inclement weather, and favors ready transport on plant material. When young plants are infested in the greenhouse and then transplanted into the field, fields will not only be inoculated with aphids but insecticide resistance may be introduced. These aphids also can be transported long distances by wind and storms.

\section{Life Cycle and Description}

The life cycle varies considerably, depending on the presence of cold winters. van Emden et al. (1969) provide a good review of the life cycle. Development can be rapid, often 10 to 12 days for a complete generation, and with over 20 annual generations reported in mild climates. Where suitable host plants cannot persist, the aphid overwinters in the egg stage on Prunus spp. In the spring, soon after the plant breaks dormancy and begins to grow, the eggs hatch and the nymphs feed on flowers, young foliage, and stems. After several generations, winged dispersants from overwintering Prunus spp. deposit nymphs on summer hosts. In cold climates, adults return to Prunus spp. in the autumn, where mating occurs, and eggs are deposited. All generations except the autumn generation culminating in egg production are parthenogenetic (non-sexual). In Florida, populations cycle continuously on annual plants.

\section{Eggs}

Eggs are deposited on Prunus spp. trees. The eggs measure about $0.6 \mathrm{~mm}$ long and $0.3 \mathrm{~mm}$ wide, and are elliptical in shape. Eggs initially are yellow or green, but soon turn black. Mortality in the egg stage sometimes is quite high.

\section{Nymphs}

Nymphs initially are greenish, but soon turn yellowish, greatly resembling viviparous

1. This document is EENY-222, one of a series of Featured Creatures from the Entomology and Nematology Department, Florida Cooperative Extension Service, Institute of Food and Agricultural Sciences, University of Florida. Published: July 2001. Revised: July 2004. This document is also available on Featured Creatures Website at http://creatures.ifas.ufl.edu. Please visit the EDIS Website at http://edis.ifas.ufl.edu. Additional information on these organisms, including many color photographs, is available at the Entomology and Nematology Department Website at http://entnemdept.ifas.ufl.edu/.

2. John L. Capinera, professor/chairman, Entomology and Nematology Department, Cooperative Extension Service, Insisitue of Food and Agricultural Sciences, University of Florida, Gainesville, FL 32611.

The Institute of Food and Agricultural Sciences (IFAS) is an Equal Employment Opportunity - Affirmative Action Employer authorized to provide research, educational information and other services only to individuals and institutions that function without regard to race, creed, color, religion, age, disability, sex, sexual orientation, marital status, national origin, political opinions or affiliations. For information on obtaining other extension publications, contact your county Cooperative Extension Service office. Florida Cooperative Extension Service / Institute of Food and Agricultural Sciences / University of Florida / Larry R. Arrington, Interim Dean 


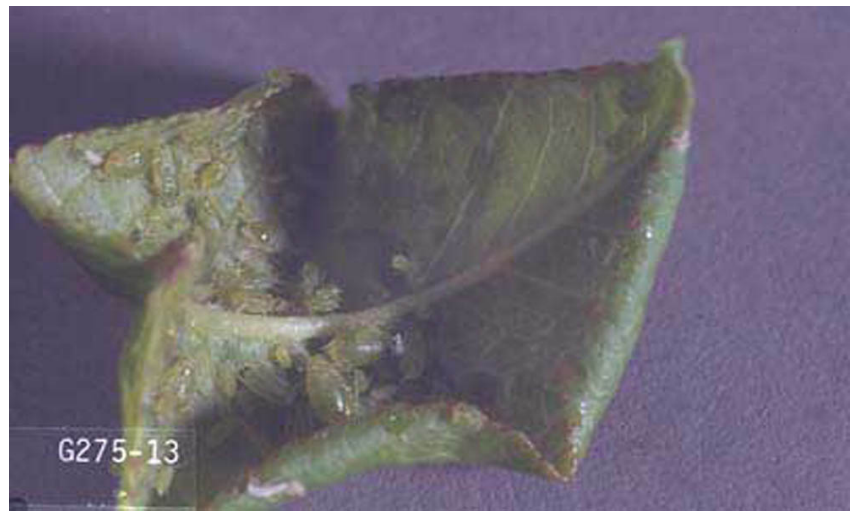

Figure 1. Colony of the green peach aphid, Myzus persicae (Sulzer), with several life stages. Credits: Ken Gray, Oregon State University

(parthenogenetic, nymph-producing) adults. Horsfall (1924) studied the developmental biology of viviparous aphids on radish in Pennsylvania. He reported four instars in this aphid, with the duration of each averaging 2.0, 2.1, 2.3, and 2.0 days, respectively. Females gave birth to offspring six to 17 days after birth, with an average age of 10.8 days at first birth. The length of reproduction varied considerably, but averaged 14.8 days. The average length of life was about 23 days, but this was under caged conditions where predators were excluded. The daily rate of reproduction averaged 1.6 nymphs per female. The maximum number of generations observed annually during these studies was determined to be 20 to 21 , depending on the year. In contrast, MacGillivray and Anderson (1958) reported five instars with a mean development time of 2.4, 1.8, 2.0, 2.1, and 0.7 days, respectively. Further, they reported a mean reproductive period of 20 days, mean total longevity of 41 days, and mean fecundity of 75 offspring.

\section{Adults}

Up to 8 generations may occur on Prunus in the spring, but as aphid densities increase winged forms are produced, which then disperse to summer hosts. Winged (alate) aphids have a black head and thorax, and a yellowish green abdomen with a large dark patch dorsally. They measure 1.8 to $2.1 \mathrm{~mm}$ in length. Winged green peach aphids seemingly attempt to colonize nearly all plants available. They often deposit a few young and then again take flight. This highly dispersive nature contributes significantly to their effectiveness as vectors of plant viruses.

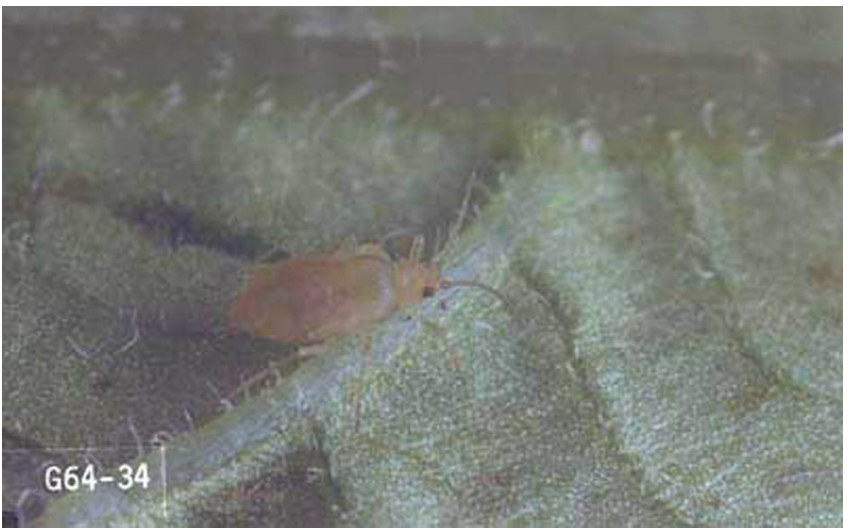

Figure 2. Nymph of the green peach aphid, Myzus persicae (Sulzer). Credits: Ken Gray, Oregon State University

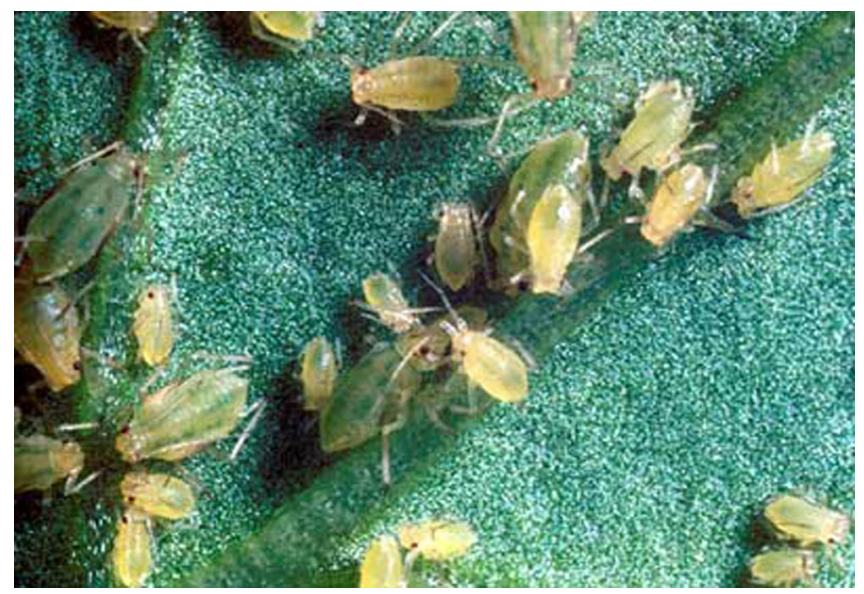

Figure 3. Female adult green peach aphid, Myzus persicae (Sulzer), with immatures. Credits: USDA

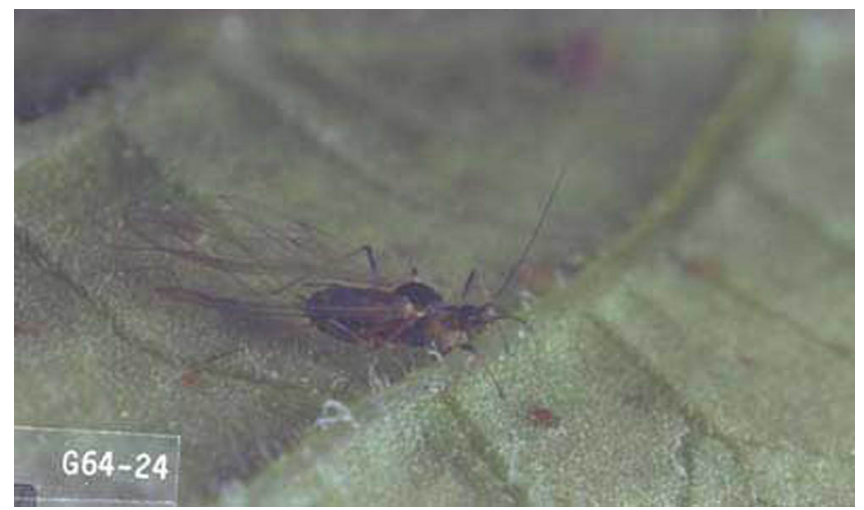

Figure 4. Adult green peach aphid, Myzus persicae (Sulzer). Credits: USDA

The offspring of the dispersants from the overwintering hosts are wingless, and each produce 30 to 80 young. The wingless (apterous) aphids are yellowish or greenish in color. They measure about 1.7 to $2.0 \mathrm{~mm}$ in length. A medial and lateral green stripes may be present. The cornicles are moderately long, unevenly swollen along their length, and match 
the body in color. The appendages are pale. The rate of reproduction is positively correlated with temperature, with the developmental threshold estimated to be about $4.3^{\circ} \mathrm{C}$. As aphid densities increase or plant condition deteriorates, winged forms are again produced to aid dispersal. The nymphs that give rise to winged females (alatae) may be pinkish. The dispersants typically produce about 20 offspring, which are always wingless. This cycle is repeated throughout the period of favorable weather. In Florida, this cycle repeats continuously, though in the northern areas of the state the aphid development rate slows greatly during the winter.

In the autumn, in response to change in day length or temperature, winged male and female aphids are produced which disperse in search of Prunus. Timing is important, as foliage on the Prunus hosts is physiologically optimal as leaves begin to senesce. Females arrive first and give birth to wingless (apterous) egg-laying forms (oviparae). Males are attracted to oviparae (egg-producing females) by a pheromone, capable of mating with several females, and eggs are produced. The oviparous female deposits four to 13 eggs, usually in crevices in and near buds of Prunus spp. The oviparous female is 1.5 to $2.0 \mathrm{~mm}$ in length, and pinkish in color.

Parthenogenic reproduction is favored in the many parts of the world where continuous production of crops provides suitable host plants throughout the year, or where weather allows survival on natural (noncrop) hosts. The average temperature necessary for survival of active forms of green peach aphid is estimated at 4 to $10^{\circ} \mathrm{C}$. Plants that readily support aphids through the winter months include beet, Brussels sprout, cabbage, kale, potato, and many winter weeds.

In the Pacific Northwest, both yellow and green strains coexist (Tamaki et al. 1982). The yellow strain is holocyclic; a sexual generation in the autumn produces overwintering eggs. The green strain is anholocyclic; no sexual generation is produced. The egg-producing populations are less tolerant of cold weather, and deposit eggs on Prunus. The anholocyclic populations remain active throughout the year by feeding during the winter on weeds growing adjacent to warm springs, drainage ditches, and slopes exposed to solar radiation.

There are several synthetic diets suitable for aphid culture, such as the one described by Mittler et al. (1970). Cottier (1953) provides a good description of green peach aphid. Keys for identification of green peach aphid, and many other common aphids, are found in Palmer (1952) and Blackman and Eastop (1984). Stoetzel et al. (1996) published a key for cotton aphids that is also useful for distinguishing green peach aphid from most other common vegetable-infesting aphids.

\section{Host Plants}

Green peach aphid feeds on hundreds of host plants in over 40 plant families. However, it is only the viviparous (giving birth to living young) summer stages that feed so widely; the oviparous (egg producing) winter stages are much more restrictive in their diet choice. In temperate latitudes the primary or overwintering hosts are trees of the genus Prunus, particularly peach and peach hybrids, but also apricot and plum. During the summer months the aphids abandon their woody hosts for secondary or herbaceous hosts, including vegetable crops in the families Solanaceae, Chenopodiaceae, Compositae, Cruciferae, and Cucurbitaceae. Vegetables that are reported to support green peach aphid include artichoke, asparagus, bean, beets, broccoli, Brussels sprouts, cabbage, carrot, cauliflower, cantaloupe, celery, corn, cucumber, fennel, kale, kohlrabi, turnip, eggplant, lettuce, mustard, okra, parsley, parsnip, pea, pepper, potato, radish, spinach, squash, tomato, turnip, watercress, and watermelon. Field crops such as tobacco, sugar beet, and sunflower also are attacked. Numerous flower crops and other ornamental plants are suitable for green peach aphid development. Stone fruit crops such as peach are sometimes damaged before the aphids leave for summer hosts. Crops differ in their susceptibility to green peach aphid, but it is actively growing plants, or the youngest plant tissue, that most often harbors large aphid populations (Heathcote 1962). In warmer climates such as Florida the aphids do not seek out overwintering hosts, but persist as active nymphs and adults on hardy crops and weeds throughout the winter months. 
Broadleaf weeds can be very suitable host plants for green peach aphid, thereby creating pest problems in nearby crops. Tamaki (1975), for example, estimated that three to16 million aphids per acre were produced on weeds growing on the floor of peach orchards in Washington, and up to one-third of the aphids feeding on weed species were carrying beet western yellows virus (BWYV) (Tamaki and Fox 1982). Peach trees are not a host of BWYV, so weeds are obviously good reservoirs for plant virus. Common and widespread weeds such as field bindweed, Convolvulus arvensis; lambsquarters, Chenopodium album; and redroot pigweed, Amaranthus retroflexus, are often cited as important aphid hosts (Annis et al. 1981).

\section{Damage}

Green peach aphids can attain very high densities on young plant tissue, causing water stress, wilting, and reduced growth rate of the plant. Prolonged aphid infestation can cause appreciable reduction in yield of root crops and foliage crops. Early season infestation is particularly damaging to potato, even if the aphids are subsequently removed (Petitt and Smilowitz 1982). Contamination of harvestable plant material with aphids, or with aphid honeydew, also causes loss. In Arkansas, mild winters allow good overwintering survival of green peach aphid on spinach, thereby leading to contamination problems (McLeod 1987). However, green peach aphid does not seem to produce the high volume of honeydew observed with some other species of aphids. Blemishes to the plant tissue, usually in the form of yellow spots, may result from aphid feeding. Leaf distortions are not common except on the primary host. Contamination of vegetables by aphids sometimes presents quarantine problems (Stewart et al. 1980), and fumigation techniques have been developed that kill the insects without causing harm to the vegetables.

The major damage caused by green peach aphid is through transmission of plant viruses. Indeed, this aphid is considered by many to be the most important vector of plant viruses throughout the world. Nymphs and adults are equally capable of virus transmission (Namba and Sylvester 1981), but adults, by virtue of being so mobile, probably have greater opportunity

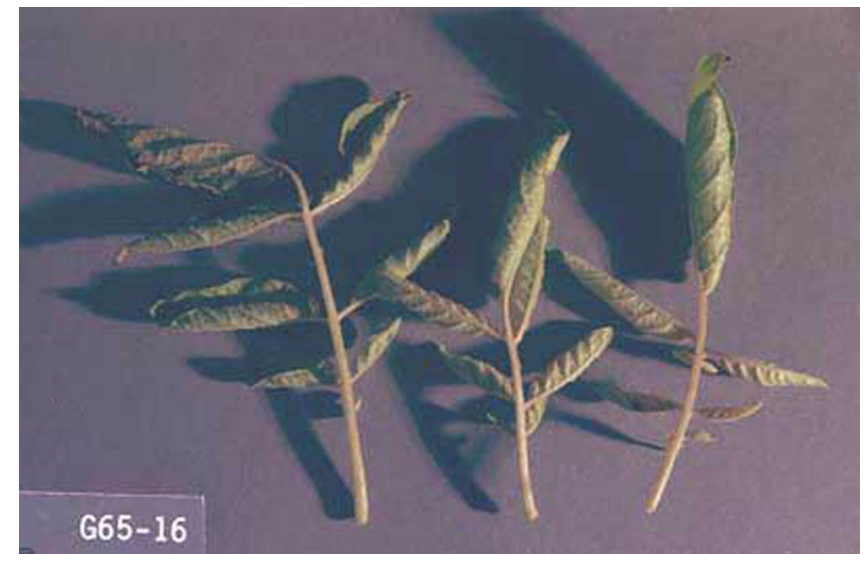

Figure 5. Damage to leaves caused by the green peach aphid, Myzus persicae (Sulzer). Credits: Ken Gray, Oregon State University

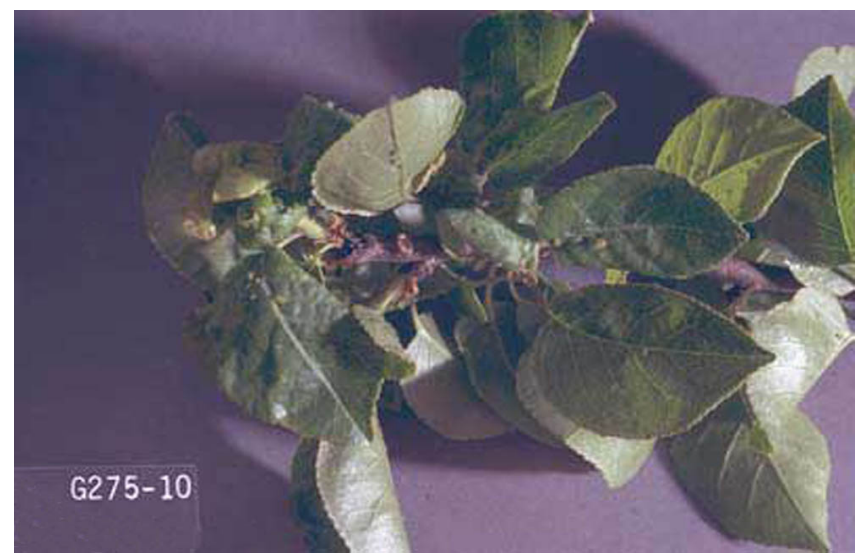

Figure 6. Damage to leaves caused by the green peach aphid, Myzus persicae (Sulzer). More than one stage in the life cycle of the aphid shown. Credits: Ken Gray, Oregon State University

for transmission. Both persistent viruses, which move through the feeding secretions of the aphid, and non-persistent viruses, which are only temporary contaminants of aphid mouthparts, are effectively transmitted. Kennedy et al. (1962) listed over 100 viruses transmitted by this species. Some of the particularly damaging diseases include potato leafroll virus and potato virus $\mathrm{Y}$ to Solanaceae, beet western yellows and beet yellows viruses to Chenopodiaceae, lettuce mosaic virus to Compositae, cauliflower mosaic and turnip mosaic viruses to Cruciferae, and cucumber mosaic and watermelon mosaic viruses to Cucurbitaceae. A discoloration in potato tubers, called net necrosis, occurs in some potato varieties following transmission of potato leafroll. 


\section{Natural Enemies}

Hundreds of natural enemies have been recorded, principally lady beetles (Coleoptera: Coccinellidae), flower flies (Diptera: Syrphidae), lacewings (Neuroptera: mainly Chrysopidae), parasitic wasps (Hymenoptera: Braconidae), and entomopathogenic fungi (mainly Entomophthorales). van Emden et al. (1969) provide a long list of beneficial organisms. Most are general predators, moving freely among green peach aphid, other aphids, and even other insects. In some cases the natural enemies are influenced by the host plant, crop cultural practices, and environmental conditions (Tamaki et al. 1981). Green peach aphid, and many other aphids, may occasionally be cannibalistic or predatory (Banks et al. 1968); however, this behavior occurs only under stressful condition and is not known to be an important factor in population regulation. Quantitative data generally are lacking for the influence of most natural enemies. Weather also reportedly contributes to significant change in aphid numbers, including direct mortality (Beirne 1972), but this also is poorly documented.

The ephemeral nature of aphid infestation in many crops is believed to prevent the beneficial organisms from consistently locating the aphids and reproducing in a timely manner. Nevertheless, there is a strong association between high aphid densities and sudden population decrease following the appearance of lady beetles, wasp parasitoids, or entomopathogenic fungi. For example, green peach aphid infesting spring-harvested spinach crops in Arkansas and Oklahoma is suppressed late in the growing season by Erynia neoaphidis fungus. Unfortunately, the disease epizootic often occurs too late to keep aphids from attaining high numbers, and fungus-infected aphids remain attached to foliage, providing a serious contaminant of spinach foliage (McLeod et al. 1998). Various studies that selectively excluded or killed beneficial organisms have demonstrated the explosive reproductive potential of these aphids in the absence of biological control agents, thus demonstrating their value in reducing damage potential. In greenhouse crops, where environmental conditions and predator, parasitoid, and pathogen densities can be manipulated, biological suppression is more effective and consistent.

Integration of chemicals with natural enemies offers promise for enhanced protection from aphid damage. Shean and Cranshaw (1991) demonstrated that Aphelinus semiflavus Howard (Hymenoptera: Encyrtidae) and Diaeretiella rapae (McIntosh) (Hymenoptera: Braconidae) differed significantly in their relative susceptibility to insecticides, depending on the chemical evaluated. Also, these parasitoids, while in the mummy stage, were less susceptible to insecticide toxicity than was green peach aphid. In general, however, insecticide use in crops is more disruptive to parasitoids than to aphids, leading to larger aphid populations. Sublethal doses of some insecticides also increase aphid reproduction (Lowery and Sears 1986).

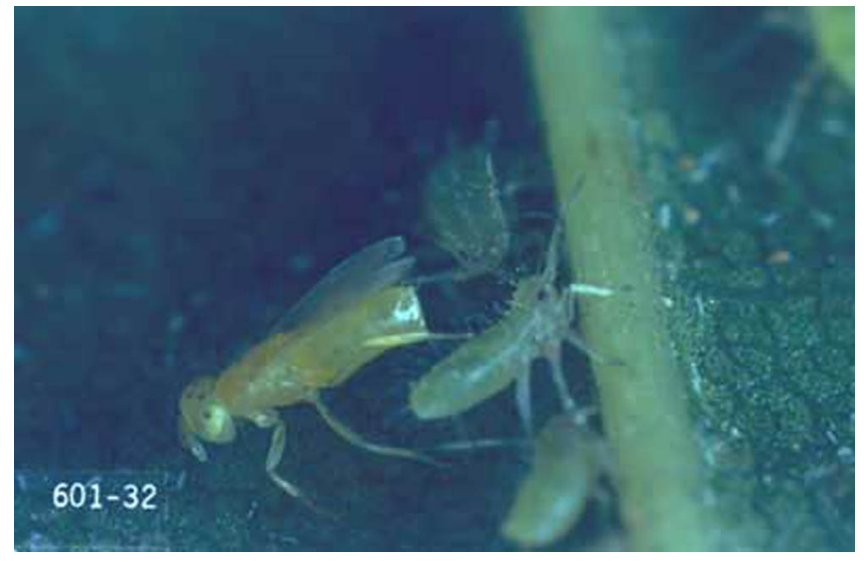

Figure 7. A Aphelinus sp.(Hymenoptera: Encyrtidae) parasitizing a green peach aphid. Credits: Ken Gray, Oregon State University

Despite the beneficial nature of these biotic agents, virus diseases can be effectively transmitted by very low aphid densities. In crops susceptible to aphid-borne virus disease, natural enemies alone are probably destined to be relatively ineffective in preventing damage.

\section{Management}

Management options for green peach aphid are very similar to procedures discussed for melon aphid, Aphis gossypii Glover. 


\section{Sampling}

Day-degree models using a developmental threshold of $4^{\circ} \mathrm{C}$ can be used to predict various phenological events such as egg hatch and immigration of alate aphids. Yellow traps, particularly water pan traps, are commonly used for population monitoring. Sequential sampling plans for green peach aphid on potato were developed by Hollingsworth and Gatsonis (1990). Sampling of aphid natural enemies in this crop were studied by Mack and Smilowitz (1980).

\section{Insecticides}

Despite the numerous options potentially available, many producers are dependent on insecticides for suppression of green peach aphid abundance. Systemic insecticide applications are especially popular at planting time, most of which provide long-lasting protection against aphid population buildup during the critical and susceptible early stages of plant growth (Powell 1980) and some of which provide protection for 3 months (Palumbo and Kerns 1994).

Green peach aphid is often a pest of cold-weather crops such as spinach. Aphids are inherently difficult to kill with contact insecticides because they are often under the leaves or on new, sheltered growth. Cold weather (less than about $20^{\circ} \mathrm{C}$ ) exacerbates the problem because there is less volatilization (fumigation) by the insecticide (Wolfenbarger 1972). Even systemic insecticides, which will kill aphids feeding under the leaf when the insecticide is applied to the upper surface, are much less effective at cool temperatures (McLeod 1991).

Excessive and unnecessary use of insecticides should be avoided. Early in the season, aphid infestations are often spotty, and if such plants or areas are treated in a timely manner, great damage can be prevented later in the season. In some cases, use of insecticides for other, more damaging insects sometimes leads to outbreaks of green peach aphid. Inadvertent destruction of beneficial insects is purported to explain this phenomenon, but aphid resistance to some types of insecticide may also be involved.
See the following Insect Management Guide sections

for current insecticide information:

Insect Management Guide for Vegetables

(

http://edis.ifas.ufl.edu/

TOPIC_GUIDE_IG_Vegetables)

Insect Management Guide for Field Crops (http://edis.ifas.ufl.edu/TOPIC_GUIDE_IG_ Field_Crops_and_Pastures)

Insect Management Guide for Ornamentals (http://edis.ifas.ufl.edu/TOPIC_GUIDE_IG_ Ornamentals)

Green peach aphids will transmit viruses to crops that they do not colonize. Insecticides have little effect on virus transmission by non-colonizing, transient aphids, though insecticides can prevent secondary transmission within crops where colonization occurs.

\section{Biological Control}

Mackauer (1968) noted that because green peach aphid was able to develop at lower temperatures than its parasitoids, the wasps were very beneficial only in benign climates or where temperature could be controlled, as in some greenhouses. Indeed, there has been considerable success using parasitoids, the entomopathogenic fungus Verticillium lecanii, and the predatory midge Aphidoletes aphidimyza (Diptera: Cecidomyiidae) for greenhouse-grown vegetables, especially in Europe (Gilkeson and Hill 1987, Milner and Lutton 1986).

In the field, biological control agents may be differentially affected by the cropping system. For example, Tamaki et al. (1981) found that the wasp Diaeretiella rapae (Hymenoptera: Braconidae) was more effective in broccoli, whereas lady beetles (Coleoptera: Coccinellidae) and bigeyed bug (Hemiptera: Lygaeidae) predators were more effective on radish.

Cultural manipulations may benefit predators and parasitoids. In Washington, bands placed around the trunks of peach trees provided good harborage for predators that may suppress the aphids in the spring, thereby reducing the number dispersing to vegetables 


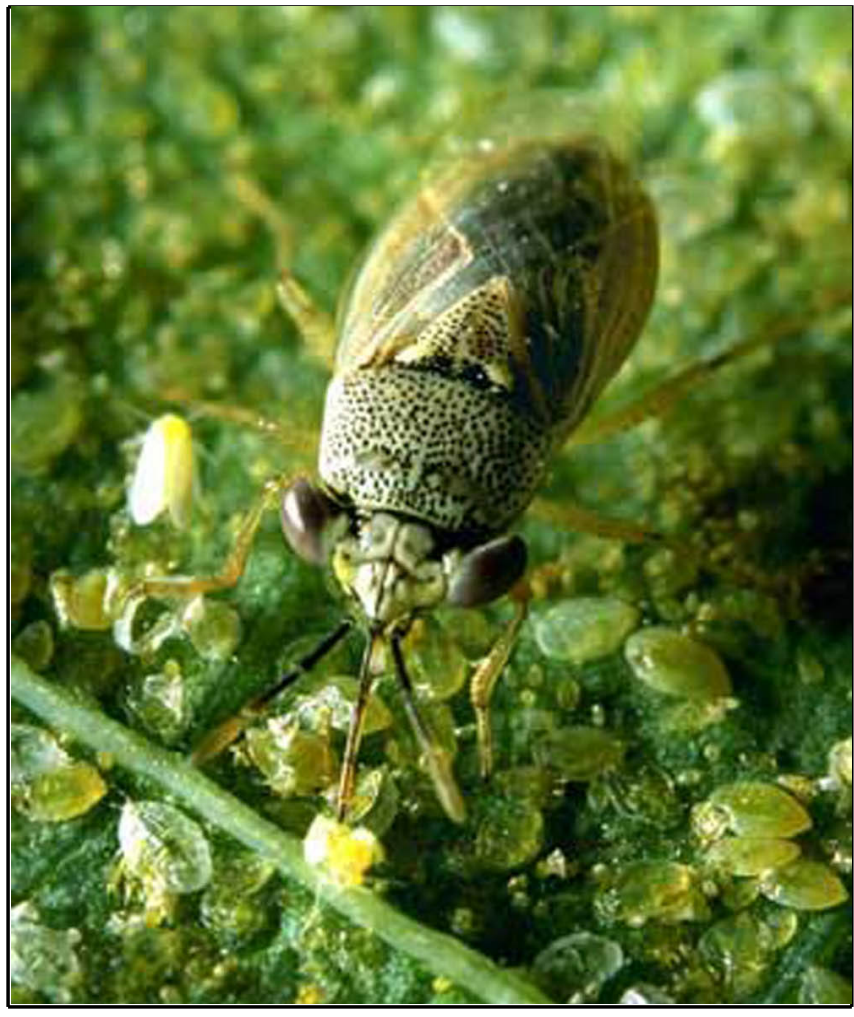

Figure 8. A bigeyed bug (Hemiptera: Lygaeidae), a predator of the green peach aphid, feeding on a whitefly. Credits: Jack Dykinga, USDA

(Tamaki and Halfhill 1968). In California, a brown lacewing (Neuroptera: Hemerobiidae) consistently reduces green peach aphid populations in asparagus, but benefits from application of supplemental food sprays (Neuenschwander and Hagen 1980). In New Zealand, pollen levels were supplemented by interplanting flowering plants with cabbage, increasing predation of aphids by flower flies (Diptera: Syrphidae) (White et al. 1995).

\section{Cultural Practices}

The overwintering behavior of green peach aphid, which in many areas is restricted to Prunus or other relatively restricted sites, has fostered research on techniques to reduce aphid abundance and disease transmission to vegetables, by either removing the overwintering site or by eliminating the aphids before they disperse to vegetables. Destruction of peach and apricot trees (often found in association with houses), and treatment of trees with dormant oil and insecticide, have been used in western states to disrupt aphid population increase and disease transmission (Powell and Mondor 1976). Similarly, vegetable and flower plants grown in greenhouses during the winter months have been shown to be an excellent source of infestation during the following spring (Bishop and Guthrie 1964), and incidence of leafroll in potatoes grown in Idaho is directly related to the abundance of aphids in home gardens. In Colorado, inspection of garden centers and treatment of seedlings found infested with aphids are important elements of the overall potato leafroll reduction effort. As is usually the case with aphids, green peach aphid populations tend to be higher when plants are fertilized liberally with nitrogen fertilizers (Jansson and Smilowitz 1986).

The wide host range of green peach aphid makes crop rotation a difficult tactic to implement successfully. Also, crops grown down-wind from infested fields are especially susceptible because aphids are weak fliers and tend to be blown about. Infested crops should be destroyed immediately after harvest to prevent excessive dispersal, and it may be possible to destroy overwintering hosts if they are weeds. If continuous cropping is implicated in retention of aphid populations then a crop-free period is needed. Row covers can be used to inhibit development of aphid populations

Small arthropods such as green peach aphid are susceptible to injury by secretions of glandular leaf hairs found on some plants, including wild potato (Tingey and Laubengayer 1981). Younger aphids are particularly susceptible. Although this is a promising source of plant resistance, this valuable trait has yet to be incorporated into popular commercial cultivars.

\section{Disease Transmission}

Because some of the virus diseases transmitted by green peach aphid are persistent viruses, which typically require considerable time for acquisition and transmission, insecticides can be effective in preventing disease spread in some crops. Research in Minnesota (Flanders et al. 1991) showed that potato leafroll virus was transmitted within the potato crop principally by wingless aphids moving from plant to plant. Infected seed potatoes are the principal source of leafroll in most potato crops, so planting disease-free seed is obviously an important step in minimizing the incidence of the disease. Growers commonly inspect fields for signs of disease, and remove and destroy infected and nearby plants, a 
process called "roguing." This procedure reduces the ability of aphids to spread disease from plant to plant. Insecticides may not keep winged aphids from alighting in a crop and quickly transmitting nonpersistent virus, but they can certainly prevent the secondary spread of virus within a crop by colonizing aphids. As is the case with other aphids, however, insecticide resistance is a severe problem in many areas. Application of mineral oil (Ferro et al. 1980, Lowery et al. 1990) and use of aluminum or white plastic mulch (Wyman et al. 1979) reduce virus transmission. Aphids that are not effectively repelled by reflective mulch seem to thrive on mulched crops (Zalom 1981) and exhibit high rates of reproduction. Therefore, even in mulched crops some aphid control is necessary.

Transmission of nonpersistent viruses such as cucumber mosaic virus can sometimes be reduced by coating the foliage with vegetable or mineral oil. Oil is postulated to inhibit virus acquisition and transmission by preventing virus attachment to the aphid's mouthparts, or to reduce probing behavior (Loebenstein and Raccah 1980). Oil seems to be most effective when the amount of disease in an area that is available to be transmitted to a crop is at a low level. When disease inoculum or aphid densities are at high levels, oils may be inadequate protection (Umesh et al. 1995). Also, some plants may be damaged by oil applications, especially during hot weather (Marco 1993).

Green peach aphid is quite responsive to alarm pheromone, which is normally produced when aphids are disturbed (Phelan et al. 1976). Application of alarm pheromone has shown the potential to disrupt virus transmission (Gibson et al. 1984), but this has yet to become an operational technology. A sex pheromone is also known from this aphid, but it functions only at short distances, and has not yet proved to be useful in aphid management (Dawson et al. 1990).

\section{Selected References}

Annis B, Tamaki G, Berry RE. 1981. Seasonal occurrence of wild secondary hosts of the green peach aphid, Myzus persicae (Sulzer), in agricultural systems in the Yakima Valley. Environmental Entomology 10:307-312.
Banks CJ, Macaulay EDM, Holman J. 1968. Cannibalism and predation by aphids. Nature 218:491.

Beirne BP. 1972. Pest insects of annual crop plants in Canada. IV. Hemiptera-Homoptera V. Orthoptera VI. Other groups. Memoirs of the Entomological Society of Canada 85. 73 pp.

Bishop GW, J.W. Guthrie. 1964. Home gardens as a source of the green peach aphid and virus diseases in Idaho. American Potato Journal 41:28-34.

Blackman RL, Eastop VF. 1984. Aphids on the World's Crops: An Identification and Information Guide. John Wiley \& Sons, Chichester, England. 466 pp.

Capinera JL. 2001. Handbook of Vegetable Pests. Academic Press, San Diego. 729 pp.

Cottier W. 1953. Aphids of New Zealand. New Zealand Department of Scientific and Industrial Research Bulletin 106. 382 pp.

Dawson GW, Griffiths DC, Merritt LA, Mudd A, Pickett JA, Wadhams LJ, Woodcock CM. 1990. Aphid semiochemicals--a review, and recent advances on the sex pheromone. Journal of Chemical Ecology 16:3019-3030.

Ferro DN, MacKenzie JD, Margolies DC. 1980. Effect of mineral oil and a systemic insecticide on field spread of aphid-borne maize dwarf mosaic virus in sweet corn. Journal of Economic Entomology 73:730-735.

Flanders KL, Radcliffe EB, Ragsdale DW. 1991. Potato leafroll virus spread in relation to densities of green peach aphid (Homoptera: Aphididae): implications for management thresholds for Minnesota seed potatoes. Journal of Economic Entomology 84:1028-1036.

Gibson RW, Pickett JA, Dawson GW, Rice AD, Stribley MF. 1984. Effects of aphid alarm pheromone derivatives and related compounds on non- and semipersistent plant virus transmission by Myzus persicae. Annals of Applied Biology 104:203-209. 
Gilkeson LA, Hill SB. 1987. Release rates for control of green peach aphid (Homoptera: Aphididae) by the predatory midge Aphidoletes aphidimyza (Diptera: Cecidomyiidae) under winter greenhouse conditions. Journal of Economic Entomology 80:147-150.

Heathcote GD. 1962. The suitability of some plant hosts for the development of the peach-potato aphid, Myzus persicae (Sulzer). Entomologica Experimentalis et Appliciata 5:114-118.

Hollingsworth CS, Gatsonis CA. 1990. Sequential sampling plans for green peach aphid (Homoptera: Aphididae) on potato. Journal of Economic Entomology 83:1365-1369.

Horsfall JL 1924. Life history studies of Myzus persicae Sulzer. Pennsylvania Agric. Agricultural Experiment Station Bulletin 185. 16 pp.

Jansson RK, Smilowitz Z. 1986. Influence of nitrogen on population parameters of potato insects: abundance, population growth, and within-plant distribution of the green peach aphid, Myzus persicae (Homoptera: Aphididae). Environmental Entomology 15:49-55.

Kennedy JS, Day MF, Eastop VF. 1962. A Conspectus of Aphids as Vectors of Plant Viruses. Commonwealth Institute of Entomology, London. $114 \mathrm{pp}$.

Larson-Vasquez B. (8 May 1995). Resistant to most insecticides. University of Florida Book of Insect Records. http://ufbir.ifas.ufl.edu/chap15.htm (22 January 2002).

Loebenstein G, Raccah B. 1980. Control of non-persistently transmitted aphid-borne viruses. Phytoparasitica 8:221-235.

Lowery DT, Sears MK. 1986. Effect of exposure to the insecticide azinphosmethyl on reproduction of green peach aphid (Homoptera: Aphididae). Journal of Economic Entomology 79:1534-1538.

Lowery DT, Sears MK, Harmer CS. 1990. Control of turnip mosaic virus of rutabaga with applications of oil, whitewash, and insecticides. Journal of Economic Entomology 83:2352-2356.
Mack TP, Smilowitz Z. 1980. The development of a green peach aphid natural enemy sampling procedure. Environmental Entomology 9:440-445.

Mackauer M. 1968. Insect parasites of the green peach aphid, Myzus persicae Sulz., and their control potential. Entomphaga 13:91-106.

Marco S. 1993. Incidence of nonpersistently transmitted viruses in pepper sprayed with whitewash, oil, and insecticide, alone or combined. Plant Diseases 77:1119-1122.

McLeod P. 1991. Influence of temperature on translaminar and systemic toxicities of aphicides for green peach aphid (Homoptera: Aphididae) suppression on spinach. Journal of Economic Entomology 84:1558-1561.

McLeod PJ, Steinkraus DC, Correll JC, Morelock TE. 1998. Prevalence of Erynia neoaphidis (Entomophthorales: Entomophthoraceae) infections of green peach aphid (Homoptera: Aphididae) on spinach in the Arkansas River Valley. Environmental Entomology 27:796-800.

Milner RJ, Lutton GG. 1986. Dependence of Verticillium lecanii (Fungi: Hyphomycetes) on high humidities for infection and sporulation using Myzus persicae (Homoptera: Aphididae) as host. Environmental Entomology 15:380-382.

Mittler TE, Tsitsipis JA, Kleinjan JE. 1970. Utilization of dehydroascorbic acid and some related compounds by the aphid Myzus persicae feeding on an improved diet. Journal of Insect Physiology 16:2315-2326.

Namba R, Sylvester ES. 1981. Transmission of cauliflower mosaic virus by the green peach, turnip, cabbage, and pea aphids. Journal of Economic Entomology 74:546-551.

Neuenschwander P, Hagen KS. 1980. Role of the predator Hemerobius pacificus in a non- insecticide treated artichoke field. Environmental Entomology 9:492-495.

Palmer MA. 1952. Aphids of the Rocky Mountain Region. Thomas Say Foundation, Vol. 5. $452 \mathrm{pp}$. 
Palumbo JC, Kerns DL. 1994. Effects of imidacloprid as a soil treatment on colonization of green peach aphid and marketability of lettuce. Southwestern Entomologist 19:339-346.

Petitt FL, Smilowitz Z. 1982. Green peach aphid feeding damage to potato in various plant growth stages. Journal of Economic Entomology 75:431-435.

Phelan P, Montgomery ME, Nault LR. 1976. Orientation and locomotion of apterous aphids dislodged from their hosts by alarm pheromone. Annals of the Entomological Society of America 69:1153-1156.

Powell DM. 1980. Control of the green peach aphid on potatoes with soil systemic insecticides: preplant broadcast and planting time furrow applications, 1973-77. Journal of Economic Entomology 73:839-843.

Powell DM, Mondor WT. 1976. Area control of the green peach aphid on peach and the reduction of potato leaf roll virus. American Potato Journal 53:123-139.

Shean B, Cranshaw WS. 1991. Differential susceptibilities of green peach aphid (Homoptera: Aphididae) and two endoparasitoids (Hymenoptera: Encyrtidae and Braconidae) to pesticides. Journal of Economic Entomology 84:844-850.

Stewart JK, Aharoni Y, Hartsell PL, Young DK. 1980. Acetaldehyde fumigation at reduced pressures to control the green peach aphid on wrapped and packed head lettuce. Journal of Economic Entomology 73:149-152.

Stoetzel MB, Miller GL, O'Brien PJ, Graves JB. 1996. Aphids (Homoptera: Aphididae) colonizing cotton in the United States. Florida Entomologist 79:193-205.

Tamaki G. 1975. Weeds in orchards as important alternate sources of green peach aphids in late spring. Environmental Entomology 4:958-960.

Tamaki G, Fox L. 1982. Weed species hosting viruliferous green peach aphids, vector of beet western yellows virus. Environmental Entomology 11:115-117.
Tamaki G, Halfhill JE. 1968. Bands on peach trees as shelters for predators of the green peach aphid. Journal of Economic Entomology 61:707-711.

Tamaki G, Annis B, Weiss M. 1981. Response of natural enemies to the green peach aphid in different plant cultures. Environmental Entomology 10:375-378.

Tamaki G, Annis B, Fox L, Gupta RK, Meszleny A. 1982. Comparison of yellow holocyclic and green anholocyclic strains of Myzus persicae (Sulzer): low temperature adaptability. Environmental Entomology 11:231-233.

Tingey WM, Laubengayer JE. 1981. Defense against the green peach aphid and potato leafhopper by glandular trichomes of Solanum berthaultii. Journal of Economic Entomology 74:721-725.

Umesh KC, Valencia J, Hurley C, Gubler WD, Falk BW. 1995. Stylet oil provides limited control of aphid-transmitted viruses in melons. California Agriculture 49:22-24.

van Emden HF, Eastop VF, Hughes RD, Way MJ. 1969. The ecology of Myzus persicae. Annual Review of Entomology 14:197-270.

White AJ, Wratten SD, Berry NA, Weigmann U. 1995. Habitat manipulation to enhance biological control of Brassica pests by hover flies (Diptera: Syrphidae). Journal of Economic Entomology 88:1171- 1176.

Wolfenbarger DO. 1972. Effects of temperatures on mortality of green peach aphids on potatoes treated with ethyl-methyl parathion. Journal of Economic Entomology 65:881-882.

Wyman JA, Toscano NC, Kido K, Johnson H, Mayberry KS. 1979. Effects of mulching on the spread of aphid-transmitted watermelon mosaic virus to summer squash. Journal of Economic Entomology 72:139-143.

Zalom FG. 1981. Effects of aluminum mulch on fecundity of apterous Myzus persicae on head lettuce in a field planting. Entomologica Experimentalis et Appliciata 30:227-230. 